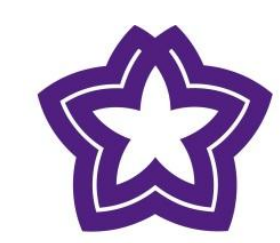

DALARNA

UNIVERSITY

Working papers in transport, tourism, information technology and microdata analysis

Predicting entry of Swedish wholesale firms into local markets

Författare 1: Johan Håkanssona

Författare 2: Zuzana Macuchova

Nr: 2013:014

Författare 3: Niklas Rudholm

Editor: Hasan Fleyeh

Working papers in transport, tourism, information technology and microdata analysis

ISSN: $1650-5581$

(c) Authors 


\title{
Predicting entry of Swedish wholesale firms into local markets
}

\author{
Johan Håkansson ${ }^{\mathrm{a}, \mathrm{b}, \mathrm{c}}$, Zuzana Macuchova ${ }^{\mathrm{b}}$ and Niklas Rudholm ${ }^{\mathrm{a}, \mathrm{b}}$ \\ ${ }^{a}$ HUI Research, SE-10329 Stockholm, Sweden; \\ ${ }^{b}$ Dalarna University, SE- 79188 Falun, Sweden; \\ ${ }^{\mathrm{c}}$ Corresponding author, phone: +46 237785 73,e-mail: jhk@du.se
}

\begin{abstract}
Applying microeconomic theory, we develop a forecasting model for firm entry into local markets and test this model using data from the Swedish wholesale industry. The empirical analysis is based on directly estimating the profit function of wholesale firms. As in previous entry studies, profits are assumed to depend on firm- and location-specific factors, and the profit equation is estimated using panel data econometric techniques. Using the residuals from the profit equation estimations, we identify local markets in Sweden where firm profits are abnormally high given the level of all independent variables included in the profit function. From microeconomic theory, we then know that these local markets should have higher net entry than other markets, all else being equal, and we investigate this in a second step, also using a panel data econometric model. The results of estimating the net-entry equation indicate that four of five estimated models have more net entry in high-return municipalities, but the estimated parameter is only statistically significant at conventional levels in one of our estimated models.
\end{abstract}

Keywords: firm location, firm entry, firm demography, spatial distribution of profits, spatial distribution of firms 


\section{Introduction}

Firm entry has long received considerable attention in the literature (e.g. Audretsch and Fritsch 1994; Troske 1996; Pakes and Ericsson 1998), and a few studies (Daunfeldt et al. 2006; Lopez-Garcia and Puente 2006; Daunfeldt et al. 2010) have also examined entry in non-manufacturing sectors of the economy.

Interest in firm entry is generally motivated by the belief that the establishment of new firms directly and indirectly brings a number of particular economic benefits (e.g. Geroski 1995). For example, high entry rates are assumed to contribute to economic growth (Carraee and Thurik 2005; Fritsch and Mueller 2008), and to stimulate innovation and increase productivity among incumbent firms (Aghion et al. 2009). Furthermore, new firms are believed to contribute to increasing employment (Baptista and Preto 2011).

Previous entry studies of the Swedish retail and wholesale trade industries (e.g. Daunfeldt et al. 2006, 2010) have assumed that firms seek to maximize profits, and that entry occurs as long as the properly discounted flow of future profits and losses is positive. These profits are assumed to depend on firm- and location-specific factors. These papers have investigated what determinants of firm entry are important in the Swedish retail and wholesale industries, but have not evaluated the predictive power of the entry models estimated.

This paper develops and evaluates a model to predict the net entry of firms into local markets. To do so, we set up a microeconomic model to identify local markets (municipalities) with abnormally high and low return on total capital. We then use data from the Swedish wholesale trade sector, and investigate whether net entry by wholesale trade firms in subsequent years is more common in the high-return than the low-return municipalities, as predicted by theory.

This paper contributes to the literature on firm entry in the wholesale trade industry, being the first paper that not only investigates the determinants of firm entry, but also evaluates the predictive power of the proposed model. The focus on wholesale trade is partly dictated by data availability, but it should also be noted that the entry model probably fits better when analyzing the entry of larger firms above a certain size. This is the case because the model uses the time and resources of potential entrants to investigate and compare profit levels in different regions. 
In Sweden, wholesale trade firms entering new markets are on average larger and have access to more resources than, for example, retail firms.

The empirical analysis and the visualization of potential entry areas are based on the direct estimation of the profit function of the wholesale firms. As in previous entry studies, profits are measured as return on total capital and are assumed to depend on firm- and location-specific factors, and the profit equation is estimated using panel data econometric techniques for the 1998-2005 period. Then, using the residuals from these estimations, we identify municipalities in Sweden where returns on capital are abnormally high and abnormally low (i.e. have large positive and negative residuals in the empirical analysis) given the level of all independent variables included in the model. Doing so, municipalities with abnormally high and low returns can be further analyzed to investigate whether abnormally high returns on capital in 1998-2005 are positively correlated with high levels of net entry by wholesale firm in subsequent years. We chose municipalities as the relevant markets to study based on previous studies (e.g. Daunfeldt et al. 2006, 2010); in addition, as demonstrated by Brandt et al. (2013), municipalities work fairly well as relevant markets in the Swedish wholesale trade industry.

The results of the panel data estimation of the profit function for the 1998-2005 period indicate that there are municipalities in Sweden where returns on capital are both abnormally high and abnormally low given the size of the independent variables included in the empirical model, and that the differences between the low- and high-return municipalities are statistically significant in all estimated models. As such, the high-return areas should be more attractive for firm entry than the low-return areas in Sweden. The results of our analysis of firm entry into local markets in 2006 and 2007 indicate that entry is indeed more common in high-return municipalities, but the differences are only statistically significant at conventional levels in one of five estimated models.

\section{Theoretical background and forecasting model}

Following Daunfeldt et al. (2006), we assume that wholesale trade firms enter a particular market with the intention of making a profit, and that firms face fixed costs. As in Daunfeldt et al. (2006), we also assume that the markets studied here are imperfectly competitive, and that firms enter a given market until the expected profits are driven to zero; this is the case until

$$
E\left[\pi_{i m}\right]=\sum_{k=1}^{K} p_{i m}^{k}\left(Q_{i m}^{k}\right) q_{i m}^{k}-\sum_{k=1}^{K} C_{i m}^{k}\left(q_{i m}^{k}\right)-F_{i m}=0
$$


where $E\left[\pi_{i m}\right]$ denotes the expected profit for potential entrant $i$ in market $m$. Following Geroski (1995), we assume that the profit expectation of a potential entrant is given by the profits of incumbents in the potential entry municipality in the pre-entry period.

In equation (1), $p_{i m}^{k}\left(Q_{i m}^{k}\right)$ is the price of product $k$ as a function of the total market sales of that product for firm $i$ in market $m, q_{i m}^{k}$ is the sales of product $k$ for the potential entrant conditional on entry, and $C_{i m}^{k}\left(q_{i m}^{k}\right)$ is the total sales costs as a function of the sales volume of product $k$. Thus, $E\left[\pi_{i m}\right]$ represents the total expected profit for a firm in the wholesale trade business selling a total of $K$ different products. The term $F_{i m}$ should be interpreted as a fixed cost corresponding to the zero profit condition. Let $F_{i m}$ take the following form:

$$
F_{i m}=\mathrm{c}_{0}+\mathbf{c}^{\prime} \boldsymbol{T}+\boldsymbol{\rho}^{\prime} \boldsymbol{X}_{i}+\boldsymbol{\eta}^{\prime} \boldsymbol{K}_{\boldsymbol{j}}+\mathbf{v}^{\prime} \boldsymbol{Z}_{\boldsymbol{m}}+\xi_{i m}
$$

Substituting (2) into (1) gives:

$$
E\left[\pi_{i m}\right]=\mathrm{c}_{0}+\mathrm{c}_{i}+\mathbf{c}^{\prime} \boldsymbol{T}+\boldsymbol{\rho} X_{i}+\boldsymbol{\eta}^{\prime} K_{j}+\mathbf{v}^{\prime} \mathbf{Z}_{\boldsymbol{m}}+\xi_{i m}
$$

where $\mathrm{c}_{i}=\sum_{k=1}^{K} p_{i m}^{k}\left(Q_{i m}^{k}\right) q_{i m}^{k}-\sum_{k=1}^{K} C_{i m}^{k}\left(q_{i m}^{k}\right)$ represents the firm-specific fixed effects included in the empirical model used below to capture the profit level in the absence of the fixed cost and of all other time-invariant heterogeneity, affecting profits, between firms.

In equation (3), $\mathbf{c}_{0}$ is a constant term and $\mathbf{T}$ is time-specific fixed effects included to capture all time-variant heterogeneity affecting firm profits. Firm profits are also allowed to depend on three vectors of variables, one reflecting firm-specific explanatory variables, $\boldsymbol{X}_{i}$, one reflecting industry location-specific variables, $\boldsymbol{K}_{j}$, and one reflecting non-industry location-specific variables, $\boldsymbol{Z}_{\boldsymbol{m}}$. The variables included in these vectors will be discussed in detail in the empirical section below. Finally, the profit function contains a component, $\xi_{i m}$, not observed by the researcher capturing anything that affects firm profits and that is not included in the above model.

Estimating the above model using firm-level data, we can calculate the predicted value of the profit for each firm and year in the dataset. Comparing this predicted value with the true observed value of the profit reveals whether 
the individual firm is performing better or worse than expected given the level of the independent variables included in the model.

In this paper, we use this predicted value to identify local markets (represented by municipalities) where profit levels are abnormally high and abnormally low given the level of the independent variables in the model. In addition, since yearly profits vary greatly, due to changed accounting rules and/or different stochastic shocks to the firm's economy, we do not use any particular year to identify municipalities with abnormal profits. Instead, we use the average value of the residual for all wholesale firms in the municipality over the period under study, 19982005.

In the next step, the predictive power of our model is evaluated by estimating the differences in net entry in lowand high-return municipalities in 2006 and 2007, using the following panel-data regression model:

$$
\text { Net entry }_{m t}=\alpha_{0}+\alpha_{m}+\alpha_{t}+\beta_{1} \text { HighRet }_{m}+\varepsilon_{m t}(4)
$$

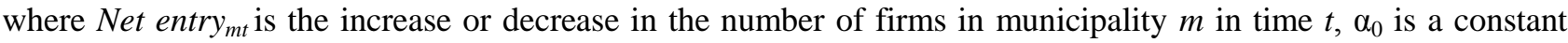
term, $\alpha_{m}$ is municipality-specific fixed effects included to capture any remaining time-invariant heterogeneity in average net entry between municipalities, and $\alpha_{t}$ is time-specific fixed effects included to capture remaining time-variant heterogeneity in net entry. HighRet $t_{m}$ is an indicator variable equal to one for high-return municipalities (to be defined in detail below) and zero for low-return municipalities. If net entry is more common in high-return municipalities, we would expect $\beta_{1}$ to be greater than zero and statistically significant.

It is difficult to determine how large the differences in returns between municipalities must be to affect firm entry behavior. The observable differences in returns on capital in Sweden are quite small, and in most cases we would not expect firms to change behavior due to these differences. In addition, since no previous research has explored this issue for the Swedish wholesale market, we estimate equation (4) using five definitions of high-return municipalities $\left(\operatorname{HighRet}_{m}\right)$. The first model compares entry into municipalities in the three lowest and three highest decentiles in terms of the size of the residuals from estimating the profit equation, the second model compares the two lowest and two highest decentiles, and the third model compares the highest and lowest decentiles. Finally, we 
also estimate models in which we compare the 20 and 15 municipalities with the highest returns with the 20 and 15 municipalities with the lowest returns.

\section{Empirical analysis}

\subsection{Data}

This study uses a dataset covering all limited liability wholesale firms in Sweden from 1998 to 2007; the dataset is provided by PAR, a Swedish consulting firm that gathers economic information from the Swedish Patent and Registration Office (Patent- och registreringsverket, PRV), to be used primarily by decision-makers in Swedish commercial life. All limited liability firms registered in Sweden are legally obliged to submit their annual financial reports to PRV. The resulting dataset, compiled by PAR, contains all variables included in firms' financial reports, such as the number of employees and measures of costs and profits. These data are frequently used in research (e.g. Daunfeldt et al. 2012a, 2012b; Håkansson et al. 2013). Data measuring municipal-level variables such as population, population density, and municipal political preference were provided by Statistics Sweden.

As we are interested in the geographical location of firms, only firms having a registered visitor's address were included in the study. Mail-order and Internet-based firms were left out of the analysis. The original dataset covered both single- and multi-plant firms; however, we chose to focus our study on only single-plant firms since the annual report data do not allow in-depth analysis of multi-plant firms. ${ }^{1}$ The study adopts the Swedish administrative divisions from year 2000, using 289 municipalities as its geographical divisions.

In total, the dataset covers 24,478 wholesale firms that were active at some point from 1998 to 2007. However, since we are interested in investigating whether we can predict the level of net entry into different municipalities using historical data on profit levels, only the years 1998-2005 are used in estimating the profit function. In addition, all firm- and industry-specific independent variables were lagged one year to reflect the potential migrant firm's decision problem resulting from the fact that firms only have access to the financial information of other firms after a one-year time lag (annual reports for 2004 are available only in summer 2005). Lagging the

\footnotetext{
${ }^{1}$ The annual financial data are aggregated to the main office (HQ) when reported to PRV. For firms with more than one place of production, it is impossible to distinguish how each plant contributes to the final results.
} 
firm-specific and industry-specific variables also alleviates a possible reversed causality problem, since previous years' values are, by definition, predetermined. Finally, data are missing for some of the independent variables (mainly the firm size and firm growth variables), leaving a dataset of 38,308 firm-years in an unbalanced panel of 11,461 wholesale firms to be used in the empirical estimations.

\subsection{Empirical model of firm profits, independent variables, and descriptive statistics}

From the theoretical discussion we know that potential entrants arrive at their profit expectations based on the previous profits of incumbent firms in the market they are planning to enter. Furthermore, following Håkansson et al. (2013), we assume that firm's profits are influenced by firm-specific and location-specific determinants; the location-specific determinants are further divided into industry-specific and non-industry-specific determinants. The location-specific geographical environment of a firm is defined as the municipality. Similar divisions into categories and variables are used elsewhere (e.g. Nakosteen and Zimmer 1987; van Dijk and Pellenbarg 2000; Daunfeldt et al. 2006; Knoben 2011).

Based on the theoretical model presented in section two, we use the following equation to explain firm profits:

$$
\mathrm{ROA}_{i m t}=\mathrm{c}_{0}+\mathrm{c}_{i}+\mathbf{c}^{\prime} \mathbf{T}+\boldsymbol{\rho} \mathbf{X}_{i}+\boldsymbol{\eta} \mathbf{K}_{j}+\mathbf{v}^{\prime} \mathbf{Z}_{\boldsymbol{m}}+\xi_{i m}
$$

where the dependent variable, ROA, is return on total assets for firm $i$ in municipality $m$ at time $t$.

The vector of firm-specific determinants, $\boldsymbol{X}_{i}$, includes firm growth (Firm growth $\left.{ }_{i t-1}\right)$, firm age (Firm age itt- $\left._{1}\right)$, and firm size (Firm size $\left.e_{i t-1}\right)$. Industry location-specific determinants, $\boldsymbol{K}_{\boldsymbol{j}}$, include the minimum efficient scale $\left(M E S_{j t-1}\right)$ in the industry in the previous year, industry size $\left(\operatorname{IndSize}(S)_{j t-1}\right)$, the number of firms $\left(\operatorname{IndSize}(F)_{j t-1}\right)$, and a Herfindahl index $\left(\operatorname{LocComp}_{j t-1}\right)$ measuring the degree of local market competition.

Minimum efficient scale denotes the smallest output a firm should produce to minimize long-term average costs. We follow Daunfeldt et al. (2012b) and measure MES as the size, in terms of sales, of the average firm in industry $j$, municipality $m$, at time $t-1$. This variable is included because, if the minimum efficient scale of operations is large, a firm entering a new market must be certain it can reach a profitable scale in a short time (e.g. Strotman 
2007, p. 89), something that will affect the profits of established firms (and the subsequent entry of other firms).

The size of the local market is measured in two ways. First, the industry size $\left(\operatorname{IndSize}(S)_{j t-1}\right)$ is measured using total sales for industry $j$ in municipality $m$. Second, we also control for the local industry size using the number of firms (IndSize $\left.(F)_{j t-1}\right)$ active in a specific industry $j$ located in municipality $m$.

The degree of local market competition is measured using a Herfindahl index ( $\left.\operatorname{LocComp}_{j t-1}\right)$. The Herfindahl index is the sum of the squared market shares of all firms, $i$, located in municipality $m$ and industry $j$. The Herfindahl index is defined on the interval $0-1$ and has a value equal to 1 if only one firm operates in the local market; if all firms in the market have equal sales, the Herfindahl index is equal to $1 /$ number of firms. Previous studies (e.g. Daunfeldt et al. 2010) have demonstrated that there is a negative correlation between highly concentrated local markets and entry by retail trade firms, which could affect profit levels as well.

The vector of non-industry location-specific determinants, $\boldsymbol{Z}_{\boldsymbol{m}}$, contains population size (PopSize $\left.e_{m t}\right)$, population density $\left(\operatorname{PopDen}_{m t}\right)$, and an indicator variable for type of local government $\left(\operatorname{LocPol}_{m t}\right)$. Population density is measured as number of inhabitants per square kilometer, and this variable is included in the model because previous research in the Netherlands (Pellenbarg et al. 2002) found that increasing land prices, along with space shortage and growing urban congestion, negatively affected the profitability of wholesale industry firms.

Finally, institutions such as local governments can also affect both firm profitability and the firm's decision to enter a specific market. Previous studies of entry in the retail trade industry in Sweden (e.g. Daunfeldt et al. 2010, 2012b) have demonstrated that firm entry occurred more frequently in municipalities with non-socialist local governments. In this paper, we thus include a dummy variable $\left(\operatorname{LocPol}_{m t}\right)$ equal to one for a non-socialist local government, and zero otherwise. We also include a variable measuring political strength $\left(\right.$ PolStr $\left._{m t}\right)$ as a Herfindahl index over the number of seats each party has in the local government. The location-specific variables also include an indicator variable equal to one if the municipality has a university or university college $\left(U n i v_{m t}\right)$, and, finally, a variable measuring the share of inhabitants in the municipality who have a university education $\left(E d u c_{m t}\right)$.

Table 1 reports the means, standard deviations, descriptions, and sources of the variables included in the empirical 
analysis.

Table 1: Descriptive statistics

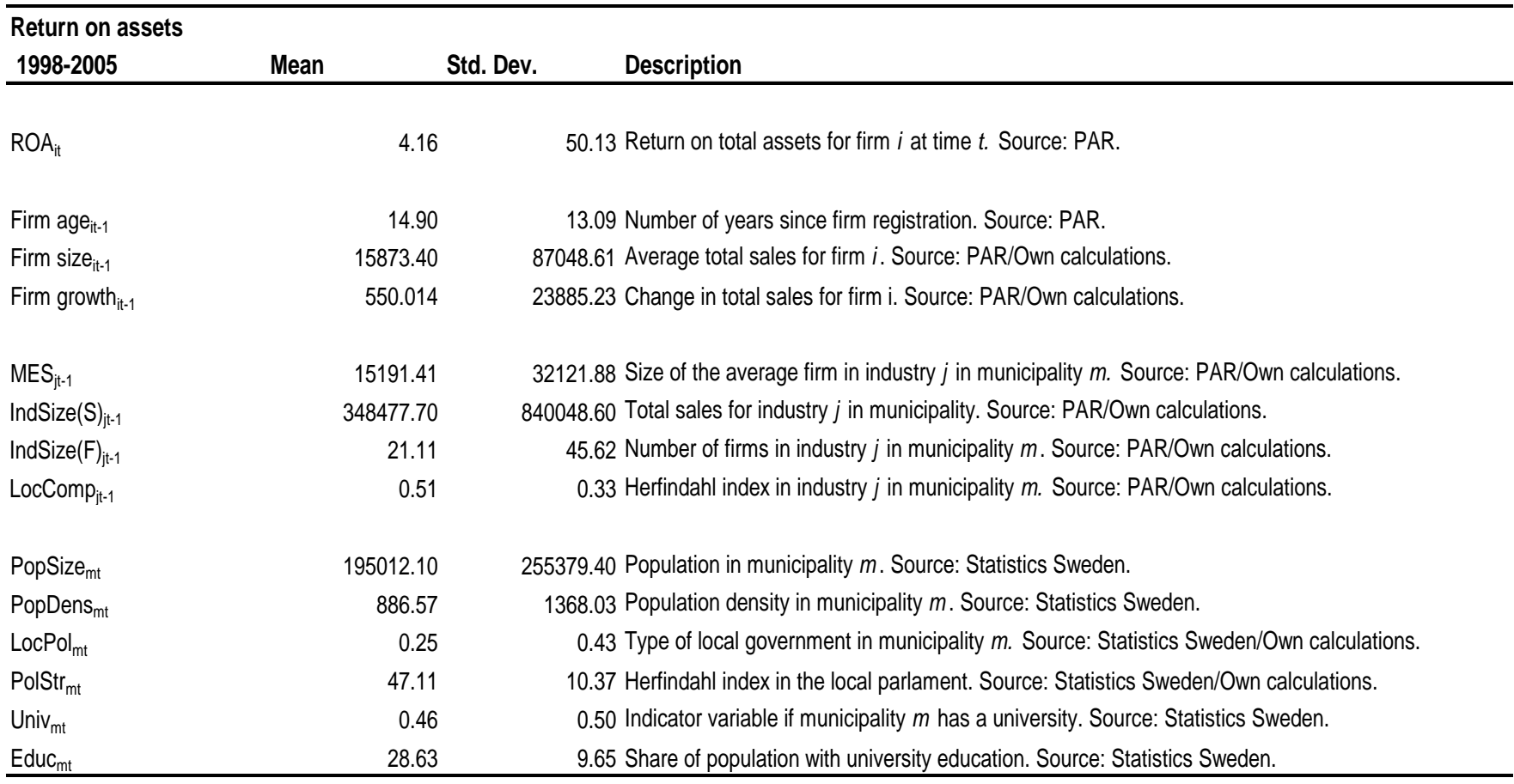

\subsection{Estimation results}

The results of estimating equation (5), Model E, and for four other models excluding some independent variables compared with Model E, are presented in Table 2. The other models estimated include only firm-related variables (Model A), only industry-specific location variables (B), only non-industry location variables (C), and one model including all these variables and firm-specific fixed effects as well (D). Finally, Model E contains all these variables as well as both firm- and time-specific fixed effects. Testing indicates that the most elaborate model fits the data best, so the following discussion of our results will focus on Model E.

In Table 2, the results indicate that only two of the independent variables included in the estimations of Model E have a statistically significant impact on firm profits, measured as return on total assets. The first is industry size measured as the number of firms, which has a small but statistically significant impact on return on assets. This probably reflects a competition effect in which the presence of several firms in the same industry and municipality compete away excess profits. The second significant finding is that firms located in municipalities with non-socialist local governments average a 3.9\% higher return on total assets than do other firms, all else being 
equal. Previous studies (e.g. Daunfeldt et al. 2010, 2012b) have also reported that entry is more common in municipalities governed by non-socialist parties.

Table 2: Estimation results, return on assets, 1998-2005.

\begin{tabular}{|c|c|c|c|c|c|c|c|c|c|c|}
\hline & Model A & & Model B & & Model C & & Model D & & Model E & \\
\hline Return on assets $1998-2005$ & Estimate & & Estimate & & Estimate & & Estimate & & Estimate & \\
\hline \multirow[t]{2}{*}{ Firm age $_{i t-1}$} & 0.055 & $* * *$ & & & & & -0.12 & & -0.31 & \\
\hline & $(0.017)$ & & & & & & $(0.23)$ & & $(0.23)$ & \\
\hline \multirow[t]{2}{*}{ Firm size $_{i t-1}$} & $-4.68 \mathrm{E}^{-7}$ & & & & & & $-8.89 \mathrm{E}^{-6}$ & & $-8.84 \mathrm{E}^{-6}$ & \\
\hline & $\left(8.33 \mathrm{E}^{-6}\right)$ & & & & & & $\left(8.09 \mathrm{E}^{-6}\right)$ & & $\left(8.03 \mathrm{E}^{-6}\right)$ & \\
\hline \multirow{2}{*}{ Firm growth ${ }_{\mathrm{it}-1}$} & 0.00014 & * & & & & & $8.84 \mathrm{E}^{-6}$ & & $8.75 \mathrm{E}^{-6}$ & \\
\hline & $(0.00008)$ & & & & & & $\left(9.11 \mathrm{E}^{-6}\right)$ & & $\left(9.10 \mathrm{E}^{-6}\right)$ & \\
\hline \multirow[t]{2}{*}{$\mathrm{MES}_{\mathrm{jt}-1}$} & & & $1.77 \mathrm{E}^{-5}$ & ** & & & $1.72 \mathrm{E}^{-6}$ & & $1.92 \mathrm{E}^{-6}$ & \\
\hline & & & $\left(8.97 \mathrm{E}^{-6}\right)$ & & & & $\left(1.12 \mathrm{E}^{-5}\right)$ & & $\left(1.12 \mathrm{E}^{-5}\right)$ & \\
\hline \multirow[t]{2}{*}{ IndSize $(S)_{\mathrm{j}-1}$} & & & $-1.22 \mathrm{E}^{-6}$ & $\star *$ & & & $-4.87 \mathrm{E}^{-7}$ & & $-5.36 \mathrm{E}^{-7}$ & \\
\hline & & & $\left(4.79 \mathrm{E}^{-7}\right)$ & & & & $\left(8.72 \mathrm{E}^{-7}\right)$ & & $\left(8.72 \mathrm{E}^{-7}\right)$ & \\
\hline \multirow[t]{2}{*}{$\operatorname{IndSize}(F)_{j t-1}$} & & & 0.0016 & & & & -0.021 & & -0.021 & * \\
\hline & & & $(0.0069)$ & & & & $(0.013)$ & & $(0.013)$ & \\
\hline \multirow[t]{2}{*}{ LocComp $_{\mathrm{jt}-1}$} & & & 1.29 & * & & & 2.97 & & 3.08 & \\
\hline & & & $(0.67)$ & & & & (2.08) & & (2.19) & \\
\hline \multirow[t]{2}{*}{ PopSize $_{m t}$} & & & & & $5.21 \mathrm{E}^{-6}$ & $* *$ & $1.18 \mathrm{E}^{-5}$ & & $1.25 \mathrm{E}^{-5}$ & \\
\hline & & & & & $\left(2.33 \mathrm{E}^{-6}\right)$ & & $\left(1.16 \mathrm{E}^{-5}\right)$ & & $\left(1.16 \mathrm{E}^{-5}\right)$ & \\
\hline \multirow[t]{2}{*}{ PopDens $_{\mathrm{mt}}$} & & & & & -0.0017 & $\star \star \star ~$ & -0.00040 & & -0.00059 & \\
\hline & & & & & $(0.00040)$ & & $(0.0017)$ & & $(0.0017)$ & \\
\hline \multirow[t]{2}{*}{$\mathrm{LocPol}_{\mathrm{mt}}$} & & & & & -0.27 & & 3.89 & $* *$ & 3.91 & ** \\
\hline & & & & & $(0.77)$ & & (1.65) & & (1.65) & \\
\hline \multirow[t]{2}{*}{ PolStr $_{m t}$} & & & & & 0.047 & & -0.032 & & -0.047 & \\
\hline & & & & & $(0.034)$ & & $(0.094)$ & & $(0.094)$ & \\
\hline \multirow[t]{2}{*}{ Univ $_{\mathrm{mt}}$} & & & & & -0.15 & & 1.94 & & 1.55 & \\
\hline & & & & & $(0.61)$ & & (4.39) & & $(4.40)$ & \\
\hline \multirow[t]{2}{*}{$\mathrm{Educ}_{\mathrm{mt}}$} & & & & & -0.079 & ** & -0.18 & & -0.12 & \\
\hline & & & & & $(0.036)$ & & $(0.21)$ & & $(0.21)$ & \\
\hline
\end{tabular}

${ }^{*}$ statistically significant at the $10 \%$ level. ${ }^{* *}$ statistically significant at the $5 \%$ level. ${ }^{* * *}$ statistically significant at the $1 \%$ level. Firm- and time specific fixed effects not reported to save space. Standard errors in parenthesis.

Finally, our results also indicate that the estimated models have very low explanatory power, and that most variables were insignificantly determined; this is in line with previous findings of firm growth studies (Reichstein and Dahl 2004; Beck et al. 2005; Fagiolo and Luzzi 2006; Coad 2009; Daunfeldt et al. 2012a), so the interpretation should be the same as in those studies. These results indicate that we know little about what determines firm profitability, but that the statistically significant firm-specific fixed effects also indicate that time-invariant firm-specific factors are important in determining firm profits. 
In the second step of our procedure, we use the residuals from estimating equation (5) above. These residuals indicate how much higher or lower a specific firm's return on total capital is versus what would be expected given the value of the independent variables in the model. Positive residuals could thus be interpreted as abnormal returns relative to what would be expected from the firm; we would then expect higher rates of net entry in high-return municipalities, all else being equal.

Figure 1: Average abnormal returns, wholesale trade industry, Sweden 1998-2005.
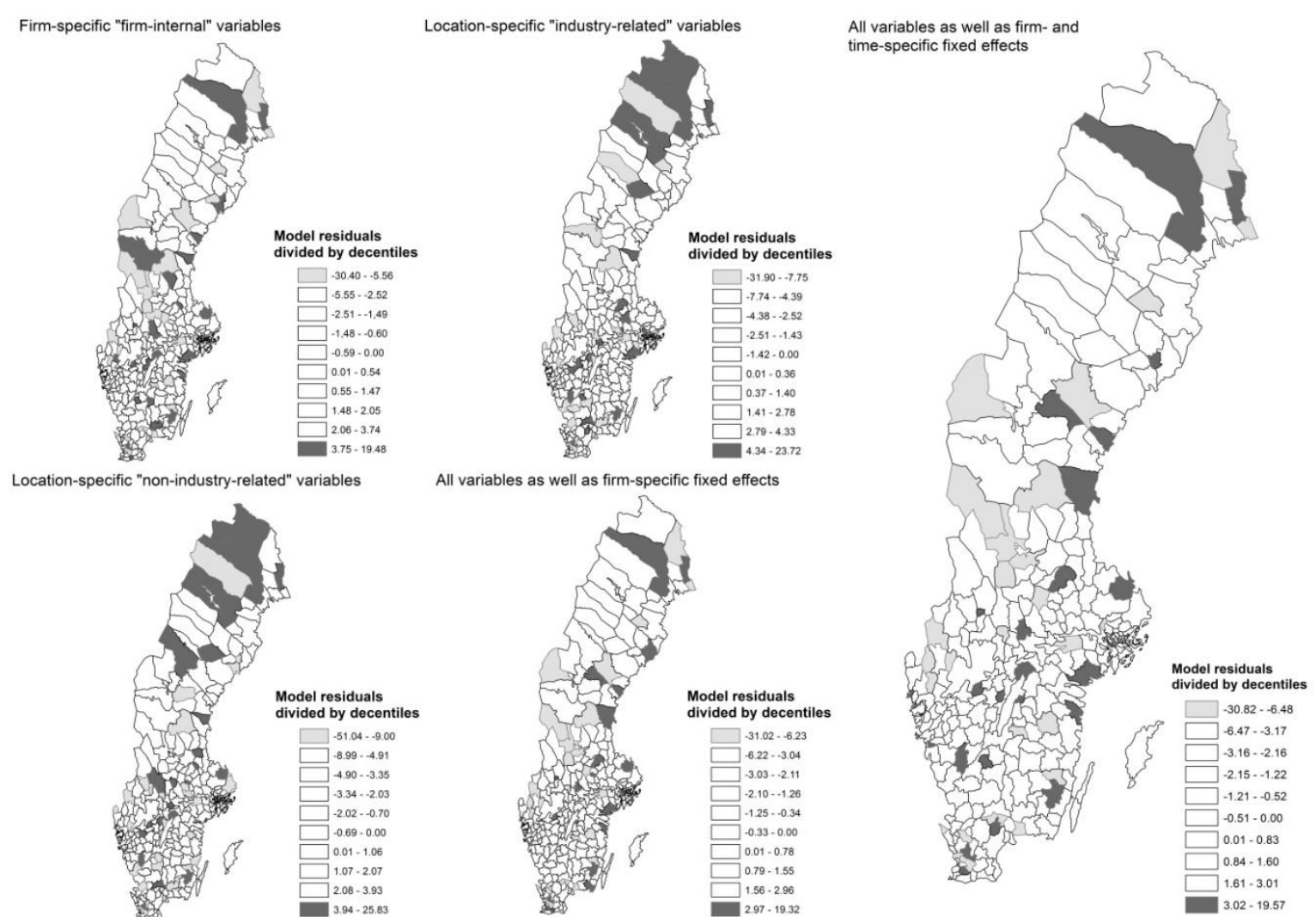

Figure 1 above presents the average residual, i.e. average abnormal return, of the wholesale firms in each municipality in 1998-2005 for models A-E. The dark shaded municipalities have residuals that are in the highest decentile of all Swedish municipalities and the light shaded are in the lowest decentile. Statistical testing also indicates that the differences between high- and low-return municipalities are statistically significant at the $1 \%$ level. For example, for model E, the average difference in return on assets between high- and low-return municipalities (highest and lowest decentile) is $13.98 \%$ ( $p$-value 0.000 ). 
Having demonstrated that there are municipal differences in returns on capital, and that these differences are statistically significant, we now turn to estimating whether low- and high-return municipalities differ when it comes to net entry of wholesale trade firms.

From the theoretical model we assume that firms actually enter a municipality until all excess profits are eliminated. In practice, however, it could be that, even if firms observe some small differences between high- and low-return municipalities, these differences might not trigger entry and exit decisions in the firms. In this paper, we therefore estimate five different models in which we study the correlation between high returns and entry using different thresholds for high/low return municipalities. Note the trade-off: The first model comparing the three lowest and highest decentiles has 569 observations in total, but the difference in returns between some of the highand low-return municipalities is not that large, so the probability of observing exit/entry based on these differences should be quite low. In the last model, the differences between the municipalities are large and it is more probable that such large differences could trigger entry or exit behavior. However, in the last model, we study only 30 municipalities (15 high return, 15 low return) over two years, giving only 60 observations in the empirical model and making it difficult to find any statistically significant effects. Thus, as we exclude municipalities that are quite similar in returns on assets, there is an increase in the probability that the observed differences are large enough to trigger entry/exit behavior, but also that we then have so few observations that these effects cannot be statistically significantly identified.

The results of estimating equation (4) from the five different models are presented in Table 3. The results indicate that, in four of five estimated models, $\beta_{1}$ is positive as expected, although not statistically significant at conventional levels in three of these models. In the model comparing the twenty municipalities with the highest returns with the twenty with the lowest, $\beta_{1}$ is positive and statistically significant. Comparing even fewer municipalities, but with even larger differences in returns on assets, gives insignificant results. Note, however, that these estimations are made based on very few observations. 
Table 3. Estimation results, net entry, 2006-2007.

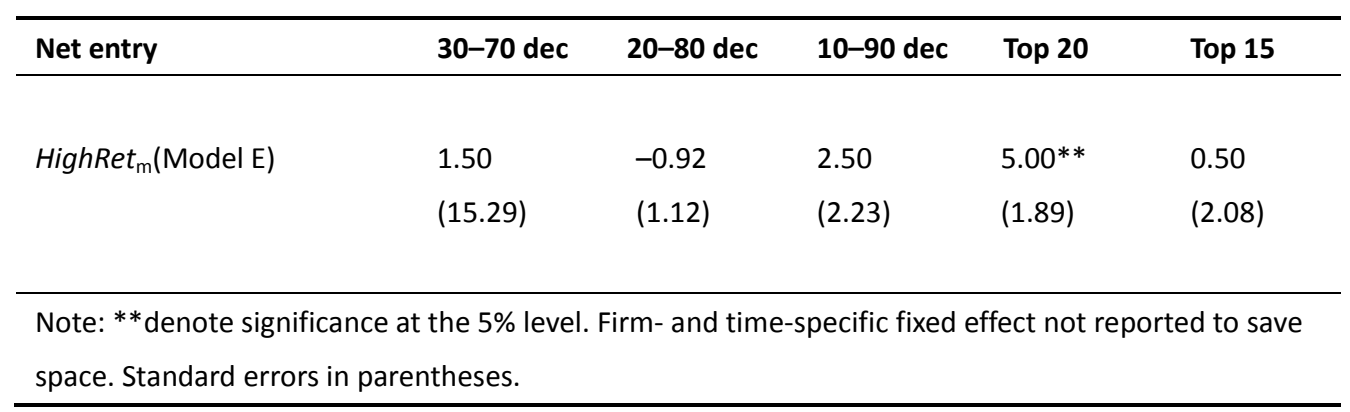

\begin{abstract}
Also note that net entry seems to increase as the difference in the level of returns on total capital increases. In the first model, 1.5 more firms net-enter the high-return municipalities; in the third model this increases to 2.5 more firms, and in the fourth model to 5.0 more firms net-entering the high-return municipalities, this difference being statistically significant at the 5\% level. However, when comparing only the top and bottom 15 municipalities, the resulting parameter estimate for being in the high-return municipality becomes statistically insignificant (although still with a positive parameter estimate).
\end{abstract}

\title{
4. Discussion
}

This paper has sought to formulate a model of firm entry, identify municipalities with abnormally high and low returns on capital using data from the Swedish wholesale trade sector, and investigate whether net entry by wholesale trade firms is more common in high- than low-return municipalities.

As in previous entry studies, profits were assumed to depend on firm- and location-specific factors, and the profit equation was estimated using firm-level data for Swedish wholesale firms for 1998-2005. Using the residuals from these estimations, municipalities in Sweden where firm profits were abnormally high or low in 1998-2005 were identified and used to investigate whether abnormal profits in 1998-2005 were positively correlated with the levels of net entry by wholesale firms in 2006 and 2007.

The results of the panel data estimation of the profit function for 1998-2005 indicate that estimation of the profit function had low explanatory power and that most variables were insignificantly determined. In addition, significant firm-specific fixed effects indicate that there is time-invariant heterogeneity in firm profits. Identifying the determinants of this heterogeneity in profits could be an area for future research using qualitative methods. 
The residuals from estimating the profit function were then used to identify municipalities in Sweden where profits were both abnormally high and abnormally low given the size of the independent variables included in the profit function. The results indicated that the differences between municipalities were statistically significant in all estimated models, although not that large in size.

We thus have the problem of deciding how large the profit differences must be for them to affect entry behavior and, since there are no clear rules or any previous literature to use as guidelines, five different empirical models were used to study whether entry was more common in high-profit municipalities. This empirical strategy forces us to make trade-offs: The first model comparing the three lowest and highest decentiles has 569 observations in total, but the differences in returns between some of the high- and low-return municipalities are small, and the probability of observing exit or entry based on these small differences is low. In the last model, the differences in profit levels between the municipalities are larger and the differences are more likely to trigger changes in entry behavior. However, the last model, comparing the 15 top and bottom municipalities for 2006 and 2007, has only 60 observations in the empirical model, making it impossible to find any statistically significant effects. A possible avenue for future research would accordingly be to try to formulate some general guidelines for choosing the number of municipalities to compare when it comes to entry behavior in relation to firm profits.

The results of our analysis of firm entry into local markets in 2006 and 2007 indicate that entry was more common in high-profit municipalities, but that the differences were only statistically significant at conventional levels in one of five estimated models. As discussed above, the method suggested here requires that the researcher make an appropriate tradeoff between having large enough differences in profits between municipalities to change entry behavior, while still keeping enough observations to be able to find statistically significant results.

\section{Acknowledgements}

We would like to thank participants at the $3^{\text {rd }}$ Nordic Retail and Wholesale Association Conference in Lund, Sweden, for their valuable comments and suggestions. Financial support from the Swedish Retail and Wholesale Development Council is gratefully acknowledged. 


\section{References}

Aghion, P., R. Blundell, R. Griffith, P. Howitt, and S. Prantl. 2009. The effects of entry on incumbent innovation and productivity. Review of Economics and Statistics 91, no. 1: 20-32.

Audretsch, D.B., and M. Fritsch. 1994. The geography of firm births in Germany. Regional Studies 28, no. 4: 35965 .

Baptista, R., and M.T. Preto. 2011. New firm formation and employment growth: Regional and business dynamics. Small Business Economics 36, no. 4: 419-42.

Beck, T., Demirguc-Kunt, A., and Maksimovic, V. 2005. Financial and legal constraints to growth: does firm size matter? The Journal of Finance 60, no. 1: 137-77.

Brandt, D., Z. Macuchova, and N. Rudholm. 2013. Entry in the Swedish wholesale trade sector: Does market definition matter? HUI Working Paper No. 81.

Carraee, A.M., and A.R. Thurik. 2005. The impact of entrepreneurship on economic growth. In: Acs, J.Z., and D.B. Audretsch (eds.), Handbook of entrepreneurship research. Dordrecht, The Netherlands: Kluwer Academic Publishers, pp. 437-72.

Coad, A. 2009. The growth of firms: A survey of theories and empirical evidence. Cheltenham, UK: Edward Elgar Publishing.

Daunfeldt, S.-O., N. Rudholm, and F. Bergström. 2006. Entry into Swedish retail and wholesale trade markets. Review of Industrial Organization 29, no. 3: 213-25.

Daunfeldt, S.-O., M. Orth, and N. Rudholm. 2010. Opening local retail food stores: A real-options approach. Journal of Industry, Competition and Trade 10, no. 3-4: 373-87. 
Daunfeldt, S.-O., Å. Lang, Z. Macuchova, and N. Rudholm. 2012a. Firm growth in the Swedish retail and wholesale trade industries. The Service Industries Journal, Online first, September 2012. doi:10.1080/02642069.2013.719883

Daunfeldt, S.-O., Elert, N, and N. Rudholm. 2012b. New start-ups and firm in-migration: Evidence from the Swedish wholesale trade industry. The Annals of Regional Science 23, no. 1: 48-64.

Fagiolo, G., and A. Luzzi. 2006. Do liquidity constraints matter in explaining firm size and growth? Some evidence from the Italian manufacturing industry. Industrial and Corporate Change 15, no. 1: 1-39.

Fritsch, M., and P. Mueller. 2008. The effect of new firm formation on regional development over time: The case of Germany. Small Business Economics 30, no. 1: 15-29.

Geroski, P.A. 1995. What do we know about entry? International Journal of Industrial Organization 13, no. 4: $421-40$.

Hayter, R. 1997. The dynamics of industrial location: The factory, the firm, and the production system. New York: Wiley.

Håkansson, J., Z. Macuchova, and N. Rudholm. 2013. Firm migration in the Swedish wholesale trade sector. International Review of Retail, Distribution and Consumer Research, 23, no. 1: 48-64.

Knoben, J. 2011. The geographical distance of relocation search: An extended resource-based perspective. Economic Geography 87, no. 4: 371-92.

Lopez-Garcia, P., and S. Puente. 2006. Business demography in Spain: Determinants of firm survival. Banco De Espana Working Paper No. 0608.

Nakosteen, R.A. and M.A. Zimmer. 1987. Determinants of regional migration of manufacturing firms. Economic 
Inquiry 15, 351-362.

Pakes, A., and R. Ericson. 1998. Empirical implications of alternative models of firm dynamics. Journal of Economic Theory 79, no. 1: 1-45.

Pellenbarg, P.H., L.J.G. van Wissen, and J. van Dijk. 2002. Firm migration. In: McCann, P. (ed.), Industrial location economics. Cheltenham, UK: Edward Elgar Publishing.

Reichstein, T., and M. Dahl. 2004. Are firm growth rates random? Analysing patterns and dependencies. International Review of Applied Economics 18, no. 2: 225-46.

Strotman, H. 2007. Entrepreneurial survival. Small Business Economics 28, no. 1: 87-104.

Troske, K.R. 1996. The dynamic adjustment process of firm entry and exit in manufacturing and finance, insurance and real estate. Journal of Law and Economics 39, no. 2: 705-35.

Van Dijk, J., and P.H. Pellenbarg. 2000. Firm relocation decisions in the Netherlands: An ordered logit approach. Papers in Regional Science 79, no. 2: 191-219. 